\title{
Laser therapy on dental emergencies of patients with hemophilia as an alternative for hemostasis and reducing the use of factor VIII concentrate
}

\section{Introduction}

Hemophilia is a hereditary disease, where the coagulation system is affected by the reduction of one of the coagulating factors, in this case factor VIII. In patients with hemophilia, oral bleeding is common, antihemophilic factor is not always available and it is extremely important to achieve hemostasis with other resources such as laser therapy.

\section{Laser (Light amplification by stimulated emission of radiation)}

Laser classification depends on low and high intensity. Bioestimulatory, analgesic and antinflamatory action are achieved by low intensity machines such As, Ga (Gallium arsenide); As, Ga, Al (Gallium and aluminum arsenide); He, Ne (hHelium, neon). High intensity laser machines produce visible and physical effects in oral tissues and can be a substitute for cold scalpel or for conventional high rotatory instrument. Er:YAG (Erbium:Ytrium-Aluminum-Garnet) Laser has bactericidal effects against periodontal pathogenic bacteria and also eliminate bacterial endotoxins. Different tissue effects according to the temperature reached in a laser machine are showed in Table 1. In these cases series the temperature oscilated between 70-90 Celsius degrees to achieve hemostasis in different types of emergency oral bleeding.

Table I Tissue effects according to the temparature reached

\begin{tabular}{ll}
\hline Temperature & Tissue effects \\
\hline $42-45^{\circ} \mathrm{C}$ & Transient hyperthermia \\
$>65^{\circ} \mathrm{C}$ & Desiccation and protein denaturation \\
$70-90^{\circ} \mathrm{C}$ & Coagulation and tissue fusion \\
$>100^{\circ} \mathrm{C}$ & Vaporization \\
$>200^{\circ} \mathrm{C}$ & Carbonization \\
\hline
\end{tabular}

\section{Objective}

To optimize the use of factor VIII in emergencies and dental treatment through the use of Er:YAG laser therapy.

\section{Material and methods}

This case series included 6 patients with an age range between 4-11 years who had different types of emergency oral bleeding (extractions, lip laceration and pulp polyp removal) for which the Er: YAG laser emission was used in order to achieve hemostasis and optimize the use of factor VIII. In extraction cases (3), a single initial dose of 25 $\mathrm{IU} / \mathrm{kg}$ / body weight was applied in two patients and the other received a dose of $50 \mathrm{IU} / \mathrm{kg} /$ body weight. In the cases of lip laceration and pulp polyp, factor was not used. In the case or dentoalveolar trauma a single initial dose of $25 \mathrm{IU} / \mathrm{kg} /$ body weight was applied (Figures 1-6).
Volume 10 Issue I - 2019

\author{
Laura Beatriz Isidro Olan,' Marco Antonio \\ Rueda Ventura, ${ }^{2}$ Carlos Alberto Balcazar \\ Najera,' Armando Najera Castro' \\ 'Master degree in Public Health, Juárez Autonomous University \\ of Tabasco, Mexico \\ ${ }^{2}$ Master degree in Medical Education, Juárez Autonomous \\ University of Tabasco, Mexico
}

Correspondence: Laura Beatriz Isidro Olan, Master degree in Public Health, Juárez Autonomous University of Tabasco, Tabasco, Mexico,Tel9933601300, Email lau.olan@hotmail.com

Received: January 25, 2019 | Published: February 20, 2019

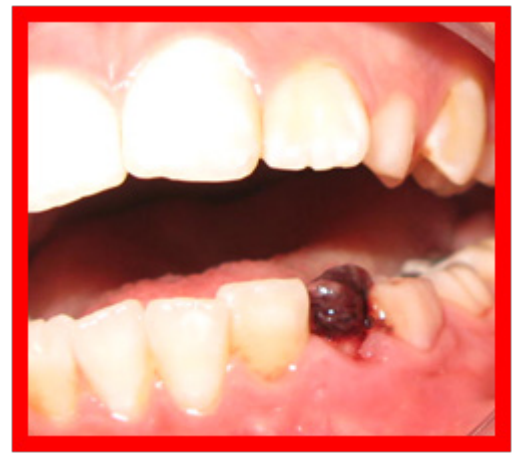

Figure I Extraction case I.

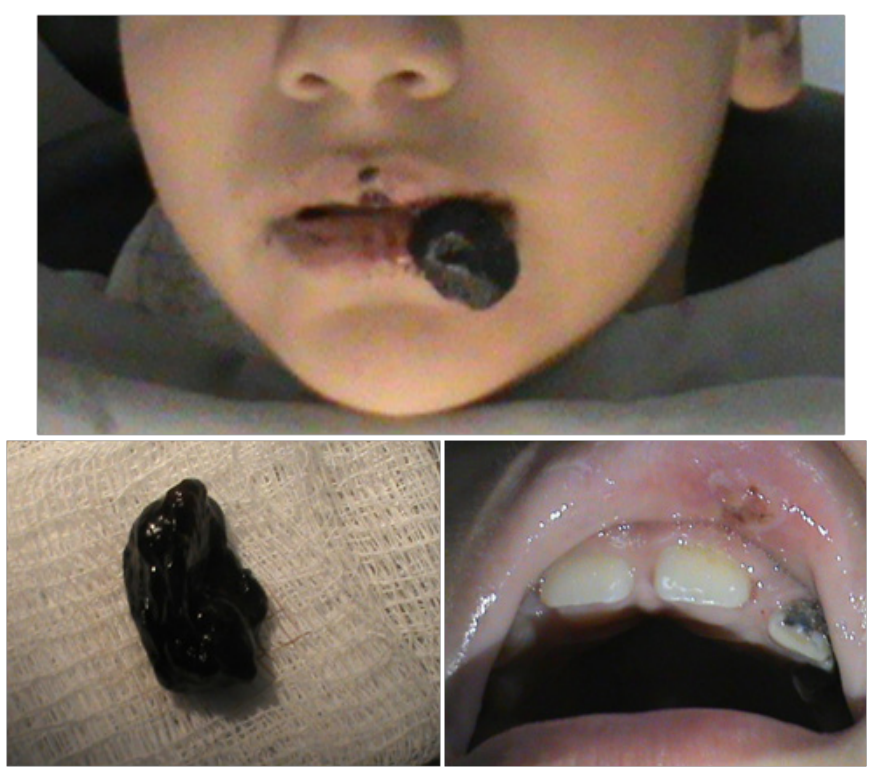

Figure 2 Upper lip lacerations (Case 2). 


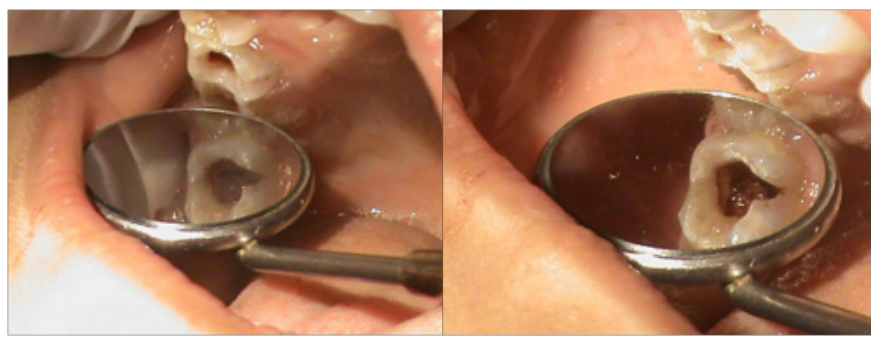

Figure 3 Pulp polyp removal (Case 3).

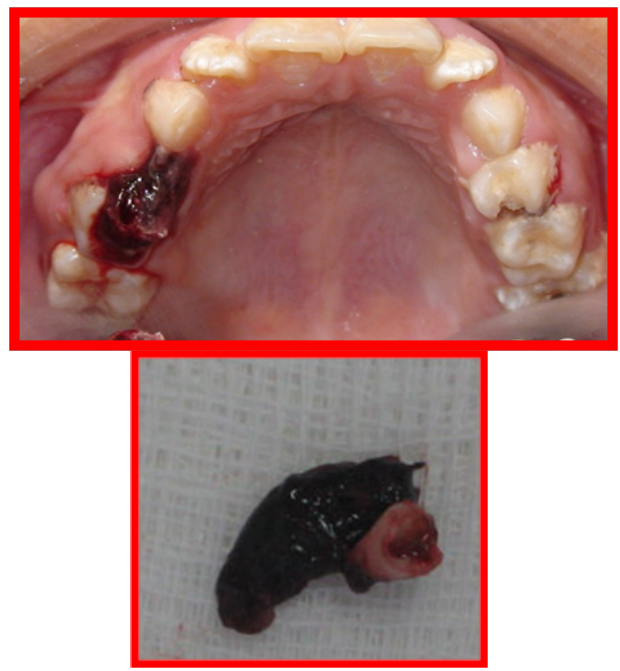

Figure 4 Extraction (Case 4)

\section{Results}

In all the cases, after the first application of the Er: YAG laser,

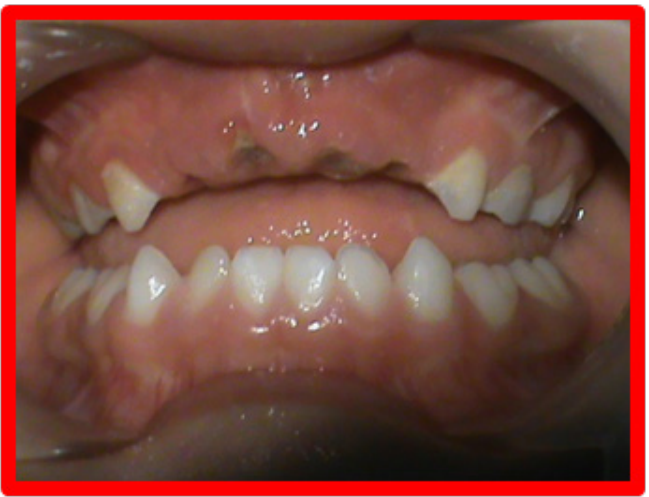

Figure 5 Multiple extractions (Case 5).

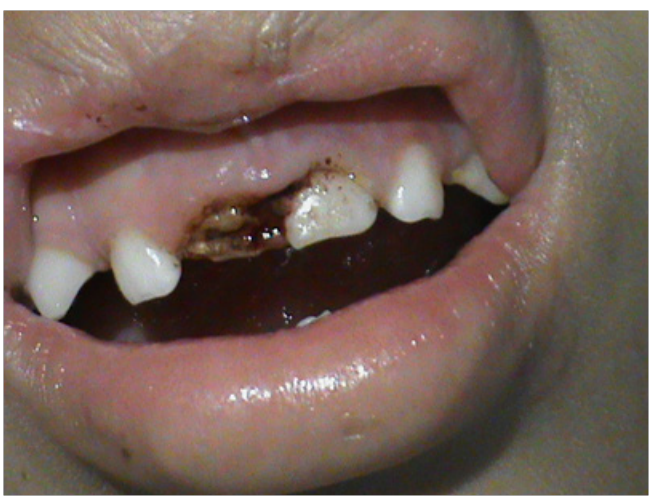

Figure 6 Dentoalveolar traumas (Case 6).

hemostasis was achieved and that allowed observation for a second application of Er: YAG if necessary. Only a second application was done in one case (Table 2).

Table 2 Reduction of Factor VIII owing to the management of the Er:YAG laser therapy

\begin{tabular}{|c|c|c|c|}
\hline & Dental diagnosis & Required factor VIII & $\begin{array}{l}\text { Factor viii owing to the management of the } \\
\text { Er: yag laser }\end{array}$ \\
\hline 1 & Temporary tooth extraction (73) & $\begin{array}{l}750 \mathrm{IU} \text { every } 12 \mathrm{hrs} / 1 \mathrm{st} \text { day ( } 2 \text { dose }) \text { y } 3 \mathrm{rd} \text { dose } 24 \mathrm{hrs} \\
\text { after }=2,250 \mathrm{IU}\end{array}$ & $25 \mathrm{IU} / \mathrm{kg}(25 \mathrm{~kg})$ single dose $=750 \mathrm{IU}$ \\
\hline 2 & Laceration of upper lip & $25 \mathrm{IU} / \mathrm{Kg} / 12 \mathrm{hrs}$ for 2 days $=2600 \mathrm{IU}$ & $25 \mathrm{IU} / \mathrm{kg}=750 \mathrm{IU}$ single dose \\
\hline 3 & Pulp polyp removal & $25 \mathrm{UI} / \mathrm{Kg} / 12 \mathrm{hrs}$ for first $24 \mathrm{hrs}=1,250 \mathrm{IU}$ & 750 IU single dose \\
\hline 4 & Temporary tooth extraction (53) & $\begin{array}{l}750 \mathrm{IU} / 8 \mathrm{hrs} * 24 \mathrm{hrs}=2,250 \mathrm{UI}, \mathrm{e} / 12 * 48 \mathrm{hrs}=3000 \mathrm{UI}, \\
\text { Total dose }=5,250 \mathrm{IU}\end{array}$ & $25 \mathrm{IU} / \mathrm{kg}=750 \mathrm{IU}$ single dose \\
\hline 5 & $\begin{array}{l}\text { Multiple extractions } \\
(52,51,61,62)\end{array}$ & $\begin{array}{l}50 \mathrm{UI} / \mathrm{Kg} / 8 \mathrm{hrs} * 1 \text { st day, e } / 12 \mathrm{hrs} * 2 \text { nd } \& 3 \text { rd days, } \\
25 \mathrm{IU} / \mathrm{Kg} / 244 \text { th } \& 5 \text { th day, same dose if necessary until } \\
\text { recovery Total dose }=10,000 \mathrm{IU}\end{array}$ & $\begin{array}{l}50 \mathrm{IU} / \mathrm{kg}(15)=750 \mathrm{IU} 1 \mathrm{st} \text { dose } ; 750 \mathrm{IU} \text { 2nd } \\
\text { dose } / 24 \mathrm{hrs} \text { after=1,500 IU }\end{array}$ \\
\hline 6 & Dentoalveolar trauma & $\begin{array}{l}25 \mathrm{IU} / \mathrm{kg}(15 \mathrm{Kg})=375 \mathrm{IU} \text { for } 3 \text { days every } 12 \mathrm{hrs}=2,250 \\
\mathrm{U.I} * * 3000 \mathrm{IU} * *\end{array}$ & $25 \mathrm{IU} / \mathrm{kg}(15 \mathrm{~kg})=375 \mathrm{IU}=* 500 \mathrm{IU}$ single dose* \\
\hline
\end{tabular}

\section{Conclusion}

In all the cases the use of the factor was reduced between 60 $80 \%$, and this also reduces the possibility to develop inhibitors. The saved factor can be used for other medical emergencies of hemophilic patients. The new alternative therapies for oral management in hemophilia patients such laser therapies, reduces pain, inflammatory responses and also patient stress.

\section{Acknowledgments}

Tabasqueña de Hemofilia A.C and Hospital de Alta Especialidad del Niño: Dr Rodolfo Nieto Padrón.

\section{Conflicts of interest}

The author declares that there is no conflicts of interest. 